\title{
Grazing effects and range trend assessment on California bighorn sheep range
}

\author{
BRIAN M. WIKEEM AND MICHAEL D. PITT
}

\begin{abstract}
This study investigated the effect of grazing by California bighorn sheep (Ovis canadensis californiana) on plant community structure. Over 28 months from 1977 to 1979, bighorn diet consisted of 79 species, including 14 grasses, 47 forbs and bryophytes, plus 18 trees and shrubs. Grasses, forbs, and shrubs comprised $66.6,18.9$, and $14.5 \%$ of the diet, respectively. Three years of bighorn sheep grazing reduced $(P<0.05)$ leaf and culm lengths of bluebunch wheatgrass (Agropyron spicatum (Pursh) Scribn. \& Smith). Grazing generally reduced leaf length, basal diameter, culm (stem) length, and culm (stem) numbers of prairie Junegrass (Koeleria cristata Pers.), Sandberg's bluegrass (Poa sandbergii Vasey), needle-and-thread (Stipa comata Trin. \& Rupr.), Thompson's paintbrush (Castilleja thompsonii Pennell), silky lupine (Lupinus sericeus Pursh), and snow buckwheat (Eriogonum niveum Dougl.). Vigor of arrowleaf balsamroot (Balsamorhiza sagittata (Pursh) Nutt.) was unaffected by grazing, despite its dietary importance. Total plant frequency remained unchanged between 1976 and 1983 in areas grazed by bighorn sheep, and in grazing exclosures. Total grass frequency declined from 46.5 to $30.8 \%$ within the exclosures, but increased from 44.7 to $48.8 \%$ in response to bighorn sheep grazing. Forb frequency remained unchanged after 7 years of bighorn sheep grazing while frequency of yarrow (Achillea millefolium L.) increased more inside exclosures than on the grazed area. Botanical composition of shrubs increased on grazed and ungrazed areas from 1976 to 1983 , but frequency was unaffected by bighorn sheep grazing. Snow buckwheat and Wyeth buckwheat (Eriogonum heracleoides Nutt.) declined in response to bighorn sheep grazing. Successional trends caused by California bighorn sheep grazing differed from trends expected from cattle grazing.
\end{abstract}

Key Words: British Columbia, forage use, grassland, habitat, Ovis canadensis californiana, plant vigor

California bighorn sheep (Ovis canadensis californiana) are distributed widely, in localized populations, from California to British Columbia (B.C.). Throughout their distribution, California bighorn use open grassland, dry forest, and alpine ranges, depending on availability. Several populations occupy grassland range for all or extended portions of the year (Sugden 1961, Drewek 1970, Morrison 1972, Ebert 1978).

Bighorn sheep can occasionally overuse individual forage plants (McCann 1956, Stelfox 1975), which may result in local overgrazing (Sugden 1961, Stelfox 1971, Morrison 1972, Ebert 1978). Although range surveys have been undertaken on a number of bighorn sheep ranges (Smith 1954, Yoakum 1964, Capp 1967, Drewek 1970, Stelfox and Spalding 1974, Stelfox 1975), few data are available to predict the effects of bighorn sheep grazing on individual plant species or plant community succession. Moreover, criteria to assess vegetation trends on mountain sheep range are

\footnotetext{
Authors are range scientist, Research Branch, British Columbia Ministry of Forests, Kamloops, B.C. V2B 8.9, and associate professor, Department of Plant Science, University of British Columbia, Vancouver, B.C. V6T 2 A2. At the time of research, the senior author was graduate student, Department of Plant Science, University of British Columbia, Vancouver, B.C.

Sandra Wikeem and Reg Newman are thanked for their assistance with field work and data analyses, respectively. The Nat. Sci. and Eng. Res. Counc. of Canada and the B.C. Fish and Wildl. Branch provided funding.

Manuscript accepted 13 December 1990.
}

currently lacking even though the need for proper range management has been recognized (Stelfox 1975, Ebert 1978).

This study quantifies grazing impacts by California bighorn sheep on individual plant species with particular emphasis on trends in frequency and botanical composition. These data, combined with forage use and plant vigor, provide a basis to identify key management species and guidelines for assessing range trend on California bighorn sheep grassland habitats.

\section{Materials and Methods}

\section{Study Area}

The study area was located $10 \mathrm{~km}$ south of Penticton, B.C., west of Skaha Lake $\left(49^{\circ} 26^{\circ} \mathrm{N}, 119^{\circ} 37^{\prime} \mathrm{W}\right)$. Derived from glacial till, soils were coarse-textured, brown chernozems (Aridic Haploboroll) of the Skaha Gravelly Sandy Loam Series (Kelly and Spilsbury 1949). Elevation of the generally steep sloping topography ranges from 550 to $750 \mathrm{~m}$ with north and northeast exposures. The site had historically been grazed by wild California bighorn sheep populations (Sugden 1961).

Chapman (1952) described the regional clımate as Middle Latitude Steppe (BSk) according to the Koppen classification. Average annual precipitation at the Penticton airport, $6 \mathrm{~km}$ north of the study site, averages $296 \mathrm{~mm}$, with bimodal peaks in January $(31.5$ $\mathrm{mm}$ ) and June $(35.6 \mathrm{~mm})$. Mean daily maximum temperatures range from $28.7^{\circ} \mathrm{C}$ in July to $-5.6^{\circ} \mathrm{C}$ in January. The average frost-free period is 143 days (Environment Canada 1974).

The vegetation is transitional between the big sagebrush (Artemisia tridentata Nutt.) and ponderosa pine (Pinus ponderosa Dougl.) zones (McLean 1970). Dominant herbaceous plants included bluebunch wheatgrass (Agropyron spicatum (Pursh) Scribn. \& Smith), cheatgrass, (Bromus tectorum L.), prairie Junegrass (Koeleria cristata Pers.), needle-and-thread (Stipa comata Trin. \& Rupr.), arrowleaf balsamroot (Balsamorhiza sagittata (Pursh) Nutt.), and Kentucky bluegrass (Poa pratensis L.). Dominant woody species included ponderosa pine and big sagebrush, with western serviceberry (Amelanchier alnifolia Nutt.), Douglas maple (Acer glabrum Nutt.), common chokecherry (Prunus virginiana L.), and common snowberry, (Symphoricarpos albus (L.) Blake) occurring in the draws.

\section{Field Methods}

In April 1977, 20 California bighorn sheep were released into a 42-ha site enclosed with perimeter fencing. The sheep foraged exclusively on native vegetation, except in January 1978, when supplemental hay was provided because of deep snow. Mineral blocks and water were provided. Following lambing each year, yearling animals were removed from the herd in order to maintain similar stocking rates and herd structure across years. Desired level of animal impact (i.e., consumption, trampling, etc.), hereafter referred to as use, was $60-70 \%$ use of annual herbaceous standing crop. This use was prescribed to induce long-term floristic changes without severely restricting opportunity for diet selection.

California bighorn sheep diet composition was estimated from microhistological fecal analysis. Voucher specimens for 75 species were photographed to prepare a dichotomous key for diet determination (Wikeem and Pitt 1983). Fifty pellet groups were composited mid-monthly for 28 months from April 1977 to August 1979. 
To assess vegetation changes caused by bighorn sheep grazing, frequency and botanical composition of all plant species were determined mid-monthly by sampling thirty-six $30-\mathrm{m}$ transects, evenly distributed over the study area with 100 Parker loops (1.9 $\mathrm{cm}$ in diameter) at 30-cm intervals (Parker 1951). These transects were stratified within 4 locations on the study site. Measurements coincided with fecal sampling from April to August in 1977 and 1978. In 1980 and 1983 all transects were sampled in mid-June to document changes in plant frequency caused by bighorn sheep grazing. Annual forage use was determined at the end of August by biomass differences (Brown 1954). Standing crop was clipped to a $5-\mathrm{cm}$ stubble height within twelve $1-\mathrm{m}^{2}$ plots randomly located on transects inside and outside 2 exclosures.

The effects of grazing on basal diameter, number of culms or stems, leaf length, and stem length of bluebunch wheatgrass, prairie Junegrass, Sandberg's bluegrass (Poa sandbergii Vasey), needle-and-thread, arrowleaf balsamroot, snow buckwheat (Eriogonum niveum Dougl.), silky lupine (Lupinus sericeus Pursh), and Thompson's paintbrush (Castilleja thompsonii Pennell) were assessed in August 1979 after 3 years of grazing. These 8 species were selected because they were abundant on the study site, occurred commonly in the sheep diet, and/or displayed high selection indices. Twenty grazed and ungrazed plants for each species were sampled at each of 3 locations.

\section{Data Summaries and Analyses}

Forage use (\%) of bluebunch wheatgrass, prairie Junegrass, needle-and-thread, cheatgrass, Sandberg's bluegrass, snow buckwheat, arrowleaf balsamroot, total forbs, total annual grass, total perennial grass, and total standing crop was calculated as:

$$
\text { Use }(\%)=\frac{\text { Ungrazed Standing Crop }- \text { Grazed Standing Crop }}{\text { Ungrazed Standing Crop }} \times 100
$$

Botanical composition was determined as the relative proportion of total plant frequency comprised by each species. Diet selection indices (SIs) for plant species were calculated as: SI = diet composition/botanical composition on the study site.

Differences among years in mean frequency and botanical composition of species were determined with analysis of covariance. Initial frequency and botanical composition data, collected in 1976 before bighorn sheep grazing, were used as covariates. Differences in basal diameter, number of culms or stems, leaf length, and stem length between ungrazed and grazed areas were also tested with analysis of variance in a randomized block design with subsampling. The 4 stratified locations were considered as blocks for experimental error, and individual plants were considered as subsamples.

\section{Results and Discussion}

Fourteen grasses, 58 forbs, and 18 shrubs were available for grazing. Seventy-eight species comprised $<1 \%$ plant frequency. Seventy-nine species occurred in the sheep diet, including all 14 grasses, $\mathbf{4 7}$ forbs and bryophytes, and 18 browse species (Wikeem 1984). Grasses, forbs, and shrubs averaged $66.6,18.9$, and $14.5 \%$ of the sheep diet, respectively, over the 28-month sampling period.

Grasses, forbs and shrubs, as respective forage groups, were grazed in approximately the same proportions as available (SI approx. $=1.0$ ). Selection indices, however, differed widely for species within these groups. Average selection indices were high for rough fescue (Festuca scabrella Torr.) (SI $=23.0)$ and prairie Junegrass $(\mathrm{SI}=4.6)$. Other species with SI values exceeding 1.0 including arrowleaf balsamroot, Thompson's paintbrush, silky lupine, snow buckwheat, and Wyeth buckwheat (Eriogonum heracleoides Nutt.). The selection index for bluebunch wheatgrass, the most abundant forage, and the most commonly occurring species in the sheep diet, was generally less than 1.0 .

Selection indices for the dominant shrub, big sagebrush, averaged approximately 0.1 . Although SIs for other subdominant shrubs, such as western serviceberry, were not calculatable, visual observations revealed the sheep browsed western serviceberry extensively, particularly during spring and winter. They virtually eliminated availability of this species after 3 years (Wikeem and Pitt 1987).

\section{Plant Vigor and Reproductive Potential}

Bluebunch wheatgrass basal diameter and culm numbers were unaffected by bighorn sheep grazing between 1977 and 1979 (Table 1). Although leaf and culm lengths were reduced $(P<0.05)$ by

Table 1. Effects of Callfornia bighorn sheep grazing on leaf length (mm), basal diameter ( $\mathrm{mm}$ ), culm length $(\mathrm{mm})$, and the number of culms

\begin{tabular}{|c|c|c|c|}
\hline Species & Variable & Grazed & Ungrazed \\
\hline Bluebunch wheatgrass & $\begin{array}{l}\text { Leaf length } \\
\text { Basal diameter } \\
\text { Culm length } \\
\text { Number of culms }\end{array}$ & $\begin{array}{r}390.3 \\
128.0 \\
603.0 \\
26.6\end{array}$ & $\begin{array}{c}413.5^{*} \\
129.5 \\
676.9^{*} \\
25.9\end{array}$ \\
\hline Prairie Junegrass & $\begin{array}{l}\text { Leaf length } \\
\text { Basal diameter } \\
\text { Culm length } \\
\text { Number of culms }\end{array}$ & $\begin{array}{r}108.5 \\
34.0 \\
329.3 \\
2.8\end{array}$ & $\begin{array}{r}166.3^{*} \\
65.4^{*} \\
399.1^{*} \\
9.5^{*}\end{array}$ \\
\hline Sandberg's bluegrass & $\begin{array}{l}\text { Leaf length } \\
\text { Basal diameter } \\
\text { Culm length } \\
\text { Number of culms }\end{array}$ & $\begin{array}{r}52.0 \\
25.2 \\
225.2 \\
3.3\end{array}$ & $\begin{array}{c}60.1^{*} \\
28.9^{*} \\
282.6^{*} \\
3.8\end{array}$ \\
\hline Needle-and-thread & $\begin{array}{l}\text { Leaf length } \\
\text { Basal diameter } \\
\text { Culm length } \\
\text { Number of culms }\end{array}$ & $\begin{array}{r}157.2 \\
32.6 \\
307.5 \\
2.8\end{array}$ & $\begin{array}{r}251.3^{*} \\
44.8^{*} \\
427.4^{*} \\
3.7^{*}\end{array}$ \\
\hline$\Lambda$ rrowleaf balsamroot & $\begin{array}{l}\text { Leaf length } \\
\text { Basal diameter } \\
\text { Stem length } \\
\text { Number of stems }\end{array}$ & $\begin{array}{r}350.0 \\
69.2 \\
65.0 \\
1.5\end{array}$ & $\begin{array}{r}370.6 \\
69.8 \\
83.6 \\
1.9\end{array}$ \\
\hline Thompson's paintbrush & $\begin{array}{l}\text { Leaf length } \\
\text { Basal diameter } \\
\text { Stem length } \\
\text { Number of stems }\end{array}$ & $\begin{array}{r}77.4 \\
21.4 \\
148.4 \\
1.7\end{array}$ & $\begin{array}{r}77.8 \\
29.3^{*} \\
244.7^{*} \\
7.2^{*}\end{array}$ \\
\hline Silky lupine & $\begin{array}{l}\text { Leaf length } \\
\text { Basal diameter } \\
\text { Stem length } \\
\text { Number of stems }\end{array}$ & $\begin{array}{r}106.2 \\
35.0 \\
19.9 \\
0.5\end{array}$ & $\begin{array}{c}318.5^{*} \\
49.5^{*} \\
345.8^{*} \\
6.4\end{array}$ \\
\hline Snow buckwheat & $\begin{array}{l}\text { Leaf length } \\
\text { Basal diameter } \\
\text { Stem length } \\
\text { Number of stems }\end{array}$ & $\begin{array}{r}56.6 \\
70.7 \\
83.3 \\
0.9\end{array}$ & $\begin{array}{r}101.4^{*} \\
108.8^{*} \\
212.8^{*} \\
7.4^{*}\end{array}$ \\
\hline
\end{tabular}
produced for 8 forage species, 1977-1979, Penticton, British Columbia.

*Means in the same row significantly different $P<0.05$.

grazing, leaf and culm lengths on the grazed plants averaged 94 and $89 \%$ of the ungrazed plants, respectively. Moderate grazing by domestic sheep in Montana produced similar effects on bluebunch wheatgrass basal diameter, leaf length, and culm length (Vogel and van Dyne 1966).

Leaf lengths, basal diameters, and culm lengths for prairie Junegrass, Sandberg's bluegrass, and needle-and-thread were all reduced by grazing (Table 1). Prairie Junegrass appeared most affected by grazing, as average basal diameter on grazed plants equalled only $52 \%$ of ungrazed plants. Conversely, basal diameters of grazed Sandberg's bluegrass plants averaged $87 \%$ of ungrazed plant diameters, whereas grazing did not affect culm production. Prairie Junegrass and needle-and-thread were used extensively in all sea- 
Table 2. Forage use of 11 vegetative groups by California bighorn sheep, 1977-1979, Penticton, British Columbia.

\begin{tabular}{lccc}
\hline \hline Vegetative Group & 1977 & 1978 & 1979 \\
\hline & 74 & $\mathrm{t}^{1}$ & 30 \\
Cheatgrass & 57 & $\mathrm{t}$ & 26 \\
Total Annual Grass & $\mathrm{t}$ & 22 & 53 \\
Bluebunch wheatgrass & 22 & 30 & 75 \\
Prairie Junegrass & $\mathrm{t}$ & $\mathrm{t}$ & 89 \\
Sandberg's bluegrass & 74 & 99 & 48 \\
Needle-and-thread & 13 & 33 & 56 \\
Total Perennial Grass & 88 & 20 & $\mathrm{t}$ \\
Arrowleaf balsamroot & 80 & 79 & 73 \\
Total Other Forbs & 83 & 93 & 86 \\
Snow buckwheat & 40 & 36 & 53 \\
Total Standing Crop & & 36 & $(\%)$ \\
\hline
\end{tabular}

'No measureable use, as biomass on the grazed plots exceeded that on ungrazed plots.

sons, generally in proportions that exceeded availability. Consistently high forage use (Table 2) likely contributed to the declining vigor of both these species.

Arrowleaf balsamroot, Thompson's paintbrush, snow buckwheat, and silky lupine responded differently to grazing by bighorn sheep between 1977 and 1979 (Table 1). Leaf length, basal diameter, culm length, and culm numbers on arrowleaf balsamroot were unaffected by grazing. In contrast, 3 years of bighorn sheep grazing reduced basal diameter and stem numbers of Thompson's paintbrush, reduced leaf length, basal diameter, and stem length of silky lupine, and reduced all vigor parameters of snow buckwheat, particularly stem numbers, which equalled only 8 and $12 \%$ of ungrazed plants, respectively.

\section{Trends in Frequency and Botanical Composition}

Most plant species and groups responded similarly between 1976 and 1983 in areas protected and in areas grazed by bighorn sheep, as indicated by nonsignificant year $\times$ grazing interactions. Indeed, trends in frequency and botanical composition over time differed $(P<0.05)$ between grazed and ungrazed areas only for soft chess, cheatgrass, total annual grass, Sandberg's bluegrass, total grass, yarrow, total forbs, Wyeth buckwheat, and snow buckwheat.

Total plant frequency remained virtually the same on the grazed and ungrazed areas after 7 years of bighorn sheep grazing (Table 3). From 1976 to 1983 , total grass frequency declined within the exclosures but remained virtually unchanged in the grazed area. Conversely, botanical composition of total grasses declined on both the grazed (63.1 vs $56.6 \%$ ) and ungrazed (67.3 vs $36.7 \%$ ) between the same years, respectively. Annual, perennial, and individual grass species all responded differently to grazing. In 1976, frequency of total annual grasses was greatest in the exclosures, whereas by 1983 this group predominated on the grazed areas (Table 3).

These differential trends for total annual grasses in grazed and ungrazed areas can be attributed primarily to bighorn sheep grazing. For example, soft chess frequency increased nearly $70 \%$ on the grazed area, but decreased $80 \%$ inside the exclosures between 1976 and 1983 (Table 3). Because soft chess comprised only a minor part of the bighorn diet, with SIs generally <1.0 (Wikeem 1984), increased soft chess frequency in grazed areas probably resulted more from altered soil surface conditions than from relative forage use. Visual observations within the exclosures indicated that a surface crust developed from 1977 to 1983 in the interspaces between bunchgrasses and low shrubs. In contrast, considerable soil disturbance occurred in the area grazed by bighorn sheep. These surface crusts inside the exclosures may have inhibited germination and establishment of grasses (Pyatt 1967), particularly annuals such as soft chess, while disturbed soil conditions in the grazed area may have provided a favorable seed bed.

The bighorn sheep grazed cheatgrass heavily during the short vernal seasonal, and in autumn when this species was most palatable. This grazing, particularly in March, April, and May before floral initiation, may impede seed production of cheatgrass, there-

Table 3. Percent frequency on areas grazed (G) and ungrazed (UG) by California bighom sheep, 1977-1983, Penticton, B.C.

\begin{tabular}{|c|c|c|c|c|c|c|c|c|}
\hline \multirow[b]{2}{*}{ Species } & \multicolumn{2}{|c|}{19761} & \multicolumn{2}{|c|}{1977} & \multicolumn{2}{|c|}{1980} & \multicolumn{2}{|c|}{1983} \\
\hline & G & U G & G & U G & $\mathbf{G}$ & U G & G & U G \\
\hline \multicolumn{9}{|l|}{ Grasses } \\
\hline Bluebunch wheatgrass & 24.2 & 16.8 & 28.8 & 19.0 & 28.5 & 22.5 & 31.9 & 20.0 \\
\hline Cheatgrass* & 10.3 & 14.8 & 13.7 & 23.8 & 18.2 & 12.5 & 2.2 & 0.8 \\
\hline Needle-and-thread & 2.8 & 4.8 & 5.6 & 9.3 & 3.8 & 5.8 & 4.4 & 4.5 \\
\hline Prairie Junegrass & 2.7 & 2.3 & 5.8 & 3.8 & 0.9 & 2.3 & 2.0 & 3.0 \\
\hline Sandberg's bluegrass* & 1.4 & 0.8 & 1.0 & 1.8 & 3.3 & 1.3 & 1.0 & 0.5 \\
\hline Soft chess* & 3.3 & 7.3 & 3.4 & 7.3 & 0.0 & 0.0 & 5.6 & 1.5 \\
\hline Total annual grass* & 13.6 & 22.0 & 13.1 & 31.7 & 20.6 & 13.5 & 9.5 & 2.8 \\
\hline Total perennial grass & 31.1 & 24.7 & 41.2 & 33.9 & 36.5 & 31.9 & 39.3 & 28.0 \\
\hline Total grass* & 44.7 & 46.7 & 54.3 & 65.6 & 57.1 & 45.4 & 48.8 & 30.8 \\
\hline \multicolumn{9}{|l|}{ Forbs } \\
\hline Arrowleaf balsamroot & 3.4 & 3.3 & $\mathbf{3 . 3}$ & 3.1 & 3.9 & 5.3 & 5.4 & 6.5 \\
\hline Brown-eyed Susan & 0.3 & 1.0 & 0.2 & 1.0 & 0.3 & 1.0 & 0.6 & 3.8 \\
\hline Nuttall's pussy-toes & 0.8 & 0.8 & 0.3 & 0.5 & 0.6 & 2.3 & 0.3 & 1.5 \\
\hline Silky lupine & 1.5 & 0.3 & 0.3 & 0.5 & 0.4 & 3.0 & 0.1 & 2.8 \\
\hline Thompson's paintbrush & 1.3 & 1.3 & 0.4 & 1.3 & 0.5 & 1.5 & 0.3 & 2.5 \\
\hline Yarrow* & 1.6 & 0.8 & 0.2 & 2.0 & 2.2 & 2.5 & 2.1 & 5.5 \\
\hline Total forbs* & 14.2 & 11.9 & 6.9 & 10.8 & 17.3 & 30.3 & 19.9 & 33.1 \\
\hline \multicolumn{9}{|l|}{ Shrubs } \\
\hline Big sagebrush & 8.8 & 11.5 & 8.8 & 10.0 & 9.6 & 9.5 & 15.2 & 17.3 \\
\hline Snow buckwheat* & 1.7 & 0.8 & 0.7 & 1.3 & 0.3 & 3.0 & 0.1 & 1.3 \\
\hline Wyeth buckwheat* & 1.0 & 0.8 & 1.1 & 0.3 & 0.4 & 0.8 & 0.1 & 0.3 \\
\hline Total shrubs & 12.6 & 13.1 & 11.8 & 11.9 & 11.2 & 13.6 & 16.6 & 19.7 \\
\hline Soil cover & 9.3 & 8.7 & 8.8 & 5.3 & 7.3 & 3.0 & 3.8 & 0.5 \\
\hline Litter cover & 18.3 & 20.0 & 12.0 & 7.3 & 6.5 & 8.6 & 8.5 & 12.3 \\
\hline Total plant cover & 71.5 & 71.7 & 77.0 & 88.3 & 85.4 & 89.3 & 85.3 & 83.6 \\
\hline
\end{tabular}


by reducing the subsequent population. Spring grazing by domestic sheep, before anthesis, nearly eliminated cheatgrass in eastern Washington (Daubenmire 1940).

Among perennial grass species, only Sandberg's bluegrass responded differently $(P<0.05)$ in grazed and ungrazed areas between 1976 and 1983. By 1983, however, frequency of this species was less on both the grazed and ungrazed areas than in 1976 (Table 3). For all other perennial grasses, including prairie Junegrass, needle-and-thread, and bluebunch wheatgrass, trends in frequency and botanical composition were similar in grazed and ungrazed areas between 1976 and 1983.

As in studies involving domestic sheep grazing (Heady et al. 1947, Teigen 1949, Mueggler 1950, Ellison 1954, Vogel and van Dyne 1966), botanical composition of forbs as a group increased $(P<0.05)$ in the exclosures $(16.4$ vs $38.5 \%)$ compared to grazed (20.2 vs $20.7 \%$ ) areas between 1976 and 1983 , respectively. Also similar to domestic sheep studies (Teigen 1949, Mueggler 1950, Ellison 1954, Branson and Lommasson 1958), the bighorn sheep generally grazed silky lupine in proportions greater than availability, particularly in spring and summer, which significantly lowered its leaf length, basal diameter, and stem numbers (Table 1). Despite this grazing, however, there were no differences $(P>0.05)$ in either frequency (Table 3) or botanical composition of silky lupine between the grazed and ungrazed areas between 1976 and 1983 .

In contrast to silky lupine, both frequency and botanical composition of yarrow increased $(P<0.05)$ between 1976 and 1983 with the greatest increases occurring within the exclosures, particularly after 1980 (Table 3). These increases in yarrow might be partly explained by both the root structure of this plant species and by bighorn sheep foraging behavior. Unlike most other forbs, yarrow has a rhizomatous root system (Ellison 1954), and in ungrazed exclosures, plants could potentially reproduce both vegetatively and sexually. In the grazed areas, bighorn sheep heavily grazed flower heads when they became available which likely limited sexual reproduction. Vegetative reproduction, however, was probably unaffected by this grazing, because yarrow only comprised a minor component of the bighorn diet during the active growing season, with SIs generally $<1.0$ (Wikeem 1984). All other forbs responded similarly over time in the grazed and ungrazed areas (Table 3).

Among shrubs, trends in frequency differed $(P<0.05)$ only for Wyeth and snow buckwheat between grazed and ungrazed areas (Table 3). High selection indices for both species (Wikeem 1984), combined with high use of snow buckwheat (Table 2), reduced plant vigor such that frequency declined in grazed areas while increasing in the exclosures between 1976 and 1983. Both of these fragile semishrubs were browsed year-round, especially during winter and spring, and were particularly susceptible to mechanical damage.

\section{Projected Long-Term Trends}

In extensive field studies, even statistically significant results are often inconclusive. For example, although vigor of Thompson's paintbrush and prairie Junegrass declined because of sheep grazing, both species displayed similar trends inside and outside the exclosures between 1976 and 1983. Indeed, for all but 6 plant species, trends between 1976 and 1983 were similar on the grazed and ungrazed transects. Conclusions regarding projected longterm trends in plant species composition associated with California bighorn sheep grazing must therefore be based on a consensus of information, including personal judgment.

Cheatgrass, Sandberg's bluegrass, Wyeth buckwheat and snow buckwheat all decreased in frequency on the grazed area from 1976 to 1983 (Table 3) and should be considered decreaser species in response to California bighorn sheep grazing in this study.

Bighorn sheep browsed big sagebrush only sparingly $(\mathrm{SI}=0.1)$.
Some minor mechanical damage, however, did occur from bighorn sheep rubbing their bodies and horns on this shrub and this species increased $(P<0.05)$ in botanical composition more on the grazed (11.9 vs $17.5 \%)$ than on the ungrazed (15.1 vs $18.2 \%$ ) between 1976 and 1983, respectively. Without excessive physical damage, big sagebrush will likely increase continually in response to bighorn sheep grazing.

Plants that increase continually in response to grazing have commonly been termed invaders for classifying range condition (Dyksterhuis 1949). The term invader, however, is inappropriate for dominant native species that comprise a significant component of the undisturbed or climax plant community. Poulton (1959) proposed that "increasers" should be divided into 2 groups: Type I, which increase initially and then decline, and Type II which are unpalatable and increase steadily under grazing pressure.

Species such as big sagebrush, therefore, should be termed "continual increasers" for bighorn sheep. The term "initial increasers" is then applied to the traditional definition of increasers as species that initially increase and then decline in response to grazing. This approach more accurately reflects plant response to grazing and avoids the potential confusion caused by the traditional assumption that only invaders continually increase in response to grazing. Classification of range condition would then include the respective proportions of both kinds of increasers up to and including the proportion expected at climax.

Plant species that can be classified as initial increasers in response to California bighorn sheep grazing in this study include bluebunch wheatgrass, needle-and-thread, arrowleaf balsamroot, and soft chess. Bluebunch wheatgrass is most vulnerable to damage by defoliation at the boot to early flowering stage (Blaisdell and Pechanec 1949, Mueggler 1975), and can be eliminated with repeated defoliations at the boot stage (Quinton et al. 1982). In our study, bluebunch wheatgrass use exceeded $50 \%$ only in the third grazing year (Table 2). Moreover, diet composition of bluebunch wheatgrass was lowest during the boot and head-emergence stages in May and early June, (Wikeem 1984), a period when bighorn sheep grazed more on forbs and other grass species.

These factors suggest that bluebunch wheatgrass may initially increase under moderate grazing by bighorn sheep. As other plant species become less available, however, this species will likely become more important for bighorn sheep, and may ultimately decline. Domestic sheep research indicates that bluebunch wheatgrass and other Agropyron spp. were unaffected or increased with sheep grazing (Heady et al. 1947, Ellison 1954, Vogel and van Dyne 1966, Bowns and Bagley 1986). Daubenmire (1940), however, suggested that bluebunch wheatgrass would eventually decline with intensive domestic sheep grazing on Palouse Prairie grassland.

Despite reduced leaf length, basal diameter, culm length, and culm numbers from bighorn sheep grazing (Table 1), needle-andthread could also be classified as an initial increaser, since trends in both botanical composition were the same on grazed and ungrazed areas (Table 3).

Similarly, frequency of arrowleaf balsamroot did not change on the grazed and ungrazed areas between 1976 and 1983 (Table 3). This species, with SIs generally averaging near 1.0 except in summer, appeared little stressed by bighorn sheep grazing, as basal diameter, stem numbers, and stem length remained unaffected after 3 years of grazing (Table 1). With moderate grazing by bighorn sheep, arrowleaf balsamroot may increase in relative botanical composition, at least initially, as other plant species decline. Research with domestic sheep, however, indicates that under prolonged and intensive spring-fall grazing this species declines (Mueggler 1950), indicating that arrowleaf balsamroot should be classified as an initial increaser.

Most annual forb species displayed low SI values, with only 
minor changes in botanical composition caused by bighorn sheep grazing (Wikeem 1984). Like soft chess, annual forbs could benefit, at least initially, from disturbance and reduced competition, as other plant species decline in response to bighorn sheep grazing.

As for domestic sheep, successional trends caused by California bighorn sheep grazing differ from successional trends normally associated with cattle. These differences reflect different grazing preferences between mountain sheep and cattle. Moreover, the qualitative terms excellent, good, fair, and poor to describe range condition classifications are not necessarily synonymous with grazing value for either cattle and sheep. For example, an excellent range condition classification in areas grazed by cattle provides a proportion of forages preferred by cattle, but may provide smaller proportions of forages preferred by California bighorn sheep.

The management emphasis on bluebunch wheatgrass as a dominant of excellent range condition for cattle should therefore not be extrapolated simplistically as a goal for bighorn sheep habitat. Optimal successional stage on California bighorn sheep habitat likely contains higher proportions of forbs and a smaller amount of bluebunch wheatgrass than does optimal successional stage for cattle. Importantly, departures from climax caused by California bighorn sheep grazing will likely produce higher proportions of bluebunch wheatgrass than at climax. These relationships illustrate that less subjective terms, such as climax, late-, mid-, and early-seral, provide more precise terminology for classifying range condition than the terms, excellent, good, fair, and poor (Pitt 1984).

\section{Literature Cited}

Blaisdell, J.P., and J.F. Pechanec. 1949. Effects of herbage removal at various dates on vigor of bluebunch wheatgrass and arrowleaf balsamroot. Ecology 30:298-305.

Bowns, J.E., and C.F. Bagley. 1986. Vegetation responses to long-term sheep grazing on mountain ranges. J. Range Manage. 39:431-434.

Branson, F.A., and T. Lommasson. 1958. Quantitative effects of twentythree years of controlled use on mountain range. J. Range Manage. 11:67-70.

Brown, D. 1954. Methods of surveying and measuring vegetation. Common. Agr. Bur., Farnham Royal, Bucks, U.K.

Capp, J.C. 1967. Competition among bighorn sheep, elk and deer in Rocky Mountain National Park, Colorado. M.S. thesis, Colorado State Univ., Fort Collins.

Chapman, J.D. 1952. The climate of British Columbia. B.C. Natur. Resour. Conf. 5:8-54.

Daubenmire, R.F. 1940. Plant succession due to overgrazing in the Agropyron bunchgrass prairie of south eastern Washington. Ecology 21:55-64.

Drewek, J. Jr. 1970. Population characteristics and behavior of introduced bighorn sheep in Owyhee County, Idaho. M.S. thesis, Univ. Idaho, Moscow.

Dyksterhuis, E.J. 1949. Condition and management of range land based on quantitative ecology. J. Range Manage. 2:104-115.

Ebert, P. 1978. Bighorn sheep in Oregon. Oregon Wildl. 33:3-6.

Ellison, L. 1954. Subalpine vegetation of the Wasatch Plateau, Utah. Ecol. Monogr. 24:89-184.

Environment Canada (Atmospheric Environment Service). 1974. Climate of British Columbia: tables of temperature and precipitation. Climatic normals 1941-1970. B.C. Dep. Agr.
Heady, H.F., R.T. Clark, and T. Lommasson. 1947. Range management and sheep production in the Bridger Mountains, Montana. Montana Exp. Sta. Bull. 444, Bozeman.

Kelley, C.C., and R.H. Spilsbury. 1949. Soil surveys of the Okanagan and Similkameen Valleys, British Columbia. Rep. No. 3. of British Columbia Survey. Kings Printer and Controller of Stationary, Ottawa, Canada.

McCann, J.L. 1956. Ecology of mountain sheep. Amer. Midl. Natur. 56:297-324.

McLean, A. 1970. Plant communities of the Similkameen Valley, British Columbia, and their relationship to soils. Ecol. Monogr. 40:403-424.

Morrison, D.C. 1972. Habitat utilization by mule deer in relation to cattle and California bighorn sheep in the Ashnola River Valley, British Columbia. M.S. thesis, Univ. British Columbia, Vancouver, Canada.

Mueggler, W.F. 1950. Effects of spring and fall grazing by sheep on vegetation of the Upper Snake River Plains. J. Range Manage. 3:308-315.

Mueggler, W.F. 1975. Rate and pattern of vigor recovery in Idaho fescue and bluebunch wheatgrass. J. Range Manage. 28:198-204.

Parker, K.W. 1951. A method for measuring trend in range condition on national forage ranges. USDA Forest Serv., Washington, D.C.

Pitt, M.D. 1984. Range condition and trend assessment in British Columbia. B.C. Minist. Forest Res. Rep. RR84004-HQ, Victoria, Canada.

Poulton, C.E. 1959. Ecology for the land manager. A clarification of ecological principles, concepts, and philosophies. Oregon State Univ. Range Sci. Mimeo.

Pyatt, F.B. 1967. The inhibitory influences of Peltigera canina on the growth and germination of graminaceous seeds and the subsequent growth of seedlings. Bryology 70:326-329.

Quinton, D.A., A. McLean, and D.G. Stout. 1982. Vegetative and reproductive growth of bluebunch wheatgrass in interior British Columbia. J. Range. Manage. 35:46-51.

Smith, D.R. 1954. The bighorn sheep in Idaho. Its status, life history and management. Idaho Game and Fish Dep. Wildl. Bull. 1.

Stelfox, J.G. 1971. Bighorn sheep in the Canadian Rockies. A history 1800-1970. Can. Field Natur. 85:101-122.

Stelfox, J.G. 1975. Range ecology of Rocky Mountain bighorn sheep in Canadian National Parks. Ph.D. Thesis, Univ. Montana, Bozeman.

Stelfox, J.G., and D.J. Spalding. 1974. Bighorn sheep ecology study. Vaseux-bighorn wildlife area. Can. Wildl. Serv. File No. 408/10 Vaseux.

Sugden, L.G. 1961. The California bighorn in British Columbia with particular reference to the Church Creek herd. B.C. Dep. Rec. and Conserv.

Teigen, M.L. 1949. Forage preferences of range sheep. M.S. thesis, Montana State Univ., Bozeman.

Vogel, W.G., and G.M. van Dyne. 1966. Vegetation responses to grazing management on a foothill sheep range. J. Range Manage. 19:80-85.

Wikeem, B.M. 1984. Forage selection by California bighorn sheep and the effects of grazing on an Artemisia-Agropyron community in southern British Columbia. Ph.D. thesis, Univ. British Columbia, Vancouver, Canada.

Wikeem, B.M., and M.D. Pitt. 1983. A manual for the identification by epidermal characteristics of 75 forage plant species of the southern interior of British Columbia. Fish and Wildl. Rep. R-5, Minist. Environ., B.C. Fish and Wildl., Victoria, Canada.

Wikeem, B.M., and M.D. Pitt. 1987. Evaluation of methods to determine use of browse by California Mountain Sheep. Wildl. Soc. Bull. $15: 430-433$.

Yoakum, J.D. 1964. Bighorn food habit-range relationships in the Silver Peak Range, Nevada. Trans. Desert Bighorn Counc. 8:95-102. 